\title{
Design and implementation of a smart monitoring system for water quality of fish farms
}

\author{
Nahla Abdul Jalil Salih ${ }^{1}$, Ihsan Jabbar Hasan², Nadhir Ibrahim Abdulkhaleq ${ }^{3}$ \\ 1,2Department of Electronic, Medical Technical Institute, Middle Technical University, Baghdad, Iraq \\ ${ }^{3}$ Department of Electronic Technology, Institute of Technology Baghdad, Middle Technical University, Baghdad, Iraq
}

\begin{tabular}{|c|c|}
\hline Article Info & ABSTRACT \\
\hline Article history: & Fish farms are one of the most important sources of profitability for farmers. \\
\hline Received Jun 21, 2018 & Therefore, these farms must be cared for and monitored continuously. \\
\hline Revised Dec 12, 2018 & to monitor the quality and temperature of the fish pond's water. This system \\
\hline Accepted Jan 17, 2019 & has been designed and implemented to measure and monitor the $\mathrm{pH}$ and the \\
\hline \multirow{7}{*}{$\begin{array}{l}\text { Keywords: } \\
\text { Arduino UNO } \\
\text { pH sensors } \\
\text { Smart monitoring } \\
\text { SMWQ } \\
\text { Temperature sensors }\end{array}$} & UNO as a microcontroller to measure the $\mathrm{pH}$ and temperature from the \\
\hline & $\begin{array}{l}\text { sensors. The data is then sent to the second part by Bluetooth. The second } \\
\text { part (the monitoring part) is a new anplication for smartphone desioned }\end{array}$ \\
\hline & 'MIT App Inventor 2', which monitors the status of the full system. The \\
\hline & 'MIT App Inventor 2' is a google software (opensource) that enables you to \\
\hline & easily build an Android application. The main advantage of this system is its \\
\hline & $\begin{array}{l}\text { ability to monitor the fish farms from long distances, with low cost and high } \\
\text { reliability. }\end{array}$ \\
\hline & $\begin{array}{r}\text { Copyright }(\odot 2019 \text { Institute of Advanced Engineering and Science. } \\
\text { All rights reserved. }\end{array}$ \\
\hline
\end{tabular}

Corresponding Author:

Ihsan Jabbar Hasan,

Department of Electronic, Medical Technical Institute,

Middle Technical University, Baghdad, Iraq.

Email: Ihsan_hssn@yahoo.com

\section{INTRODUCTION}

According to research in the technology industry, there has been a steady evolution in smart surveillance systems, especially in the Medical and Agricultural industries [1]-[7]. For the purpose of increasing the reliability of electrical and electronic devices, the focus was on smart monitoring and control systems. The smart monitoring system design and implemented for water quality of fish farms is new. This system is called 'Smart Monitoring System for Water Quality of Fish Farms' (SMWQ). Figure 1 shows the full monitoring system of the SMWQ. The paper aims to design the implantation of a new smart monitoring system for agricultural application [8]-[13]. The SMWQ can be divided into two parts: the measuring circuit and the monitoring application; a) The measuring circuit can be divided into four parts: 1) $\mathrm{A} \mathrm{pH}$ sensor to measure the acidity or alkalinity of water. 2) A temperature sensor unit, which is used to measure the water temperature. 3) An Arduino UNO as a microcontroller unit. This Arduino is used for reading $\mathrm{pH}$ and temperature from units of the sensor, then send data to end -user (Android smartphone) using Bluetooth as a wireless communication system [7], [14-20]. The main advantage of using an Arduino UNO controller is that this application is a code of an opensource and cheaper. 4) A HC-5 Bluetooth unit as a communication device [21]; b) The smartphone application was designed using 'MIT App Inventor 2' [22]. The 'MIT App Inventor 2' is an opensource environment code application that creates Android smartphone applications. The advantage from this work is designing new system of smart monitoring for fish farms that has a low cost and a high reliability. 
This paper organised as following: section2 discusses relevant (work and research), section3 presents the system description of SMWQ, section4 discuss the hardware practical system and smartphone application, finally section 5 offers conclusions and potential further work.

\section{RELATED WORK}

This section considers this monitoring system in comparison to work related at the same field, like similar research use a different type of sensors, a different type of wireless communication, a different type for microprocessors, also different monitoring applications. The research is presented in Table 1.

The SMWQ that designed and implemented consists of: $\mathrm{pH}$ and Temperature water sensors, Bluetooth HC-05, an Arduino UNO as a microprocessor, and a new smartphone application for an Android smartphone.

Table 1. Related research for smart monitoring and control systems

\begin{tabular}{|c|c|c|c|c|c|}
\hline $\begin{array}{l}\text { Related Work } \\
\text { Reference }\end{array}$ & Field & $\begin{array}{c}\text { Type of } \\
\text { Monitoring } \\
\text { System } \\
\end{array}$ & Type of Sensors & $\begin{array}{c}\text { Type of } \\
\text { Communication } \\
\text { System }\end{array}$ & $\begin{array}{c}\text { Type of } \\
\text { Microcontroller }\end{array}$ \\
\hline $\begin{array}{l}\text { J. K. Abed [1], } \\
2018\end{array}$ & DC/DC converter & $\begin{array}{l}\text { Smartphone } \\
\text { Application }\end{array}$ & Voltage/Current & Bluetooth & Arduino Nano \\
\hline $\begin{array}{l}\text { A. Jamaluddin et } \\
\text { al. [2], } 2017\end{array}$ & Battery application & $\begin{array}{l}\text { Graphic User } \\
\text { Interface }\end{array}$ & Current & Wiring & $\begin{array}{c}\text { ATmega-328 and } \\
\text { ATmega-2560 }\end{array}$ \\
\hline $\begin{array}{l}\text { T. S. Gunawan et } \\
\text { al. [3], } 2017\end{array}$ & Smart Home & Website GUI & $\begin{array}{c}\text { Gas, PIR, } \\
\text { Temperature and } \\
\text { ultrasonic sensors. }\end{array}$ & $\begin{array}{c}\text { APC220 Wireless } \\
\text { and } \\
\text { Ethernet Shield }\end{array}$ & Arduino Mega \\
\hline $\begin{array}{c}\text { M. J. Mnati et al. } \\
{[5], 2017}\end{array}$ & Power application & $\begin{array}{l}\text { Smartphone } \\
\text { Application }\end{array}$ & Voltage/ Current & Bluetooth & Arduino Nano \\
\hline $\begin{array}{c}\text { S. Ghazali et al. } \\
{[4], 2017}\end{array}$ & $\begin{array}{l}\text { grid-tied PV } \\
\text { monitoring } \\
\text { application }\end{array}$ & Website GUI & $\begin{array}{l}\text { DHT22, current } \\
\text { voltage sensors }\end{array}$ & $\begin{array}{c}\text { ZigBee and Web } \\
\text { Server }\end{array}$ & Arduino Mega \\
\hline
\end{tabular}

\section{SYSTEM DESCRIPTION OF SMWQ}

This section will explain the full system of SMWQ, as seen in Figure 1. Figure 1 of the SMWQ can be divided into two parts: the sensors and the monitor. The sensors (the hardware circuits) are divided into the sensors and the Arduino UNO, which acts as a microcontroller. The monitoring part is a new smartphone application that is designed to monitor the status of the system.

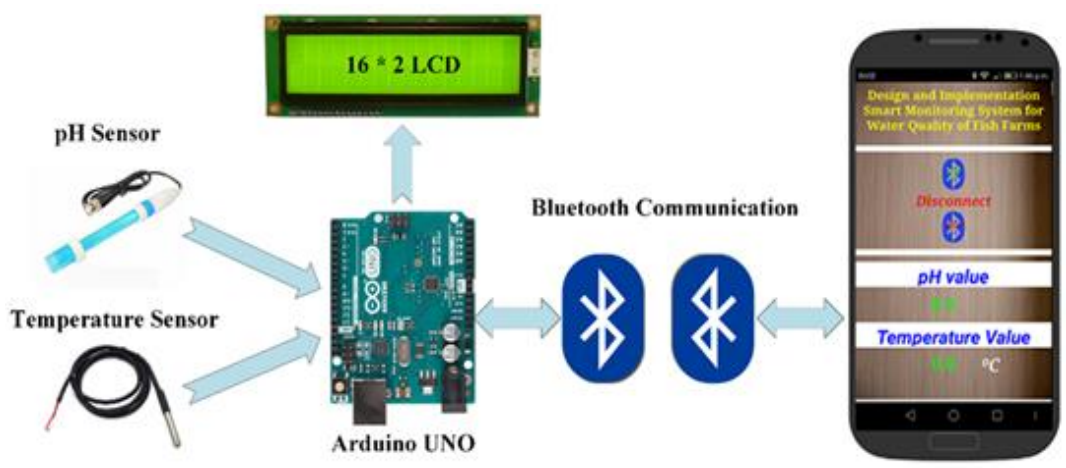

Figure 1. Full monitoring system diagram of SMWQ

\subsection{The Sensors (Hardware Circuit Design)}

The sensors, or the hardware circuits, in Figure 1 have been designed for measuring $\mathrm{pH}$ and temperature for fish farm's water. The Arduino UNO uses the sensors to read the $\mathrm{pH} /$ temperature and, after reading the data, the Arduino UNO presents the results on $16^{* 2} \mathrm{LCD}$ and sends the results to the end user by Bluetooth. The sensors circuit in SMWQ system includes main units as follows:

1) Arduino UNO unit.

2) Bluetooth unit. 
3) $\mathrm{pH}$ sensor unit.

4) Temperature sensor unit.

The main units of the sensors circuit are shown in Figure 2.

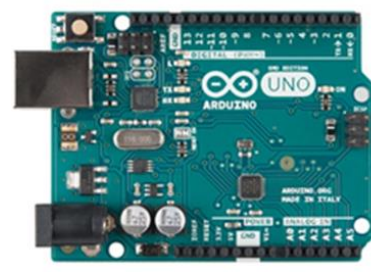

(a)

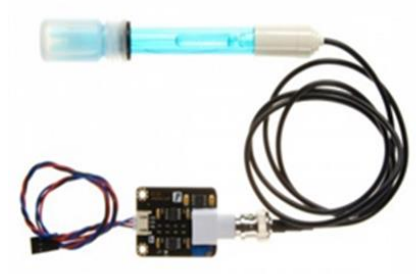

(c) (b)
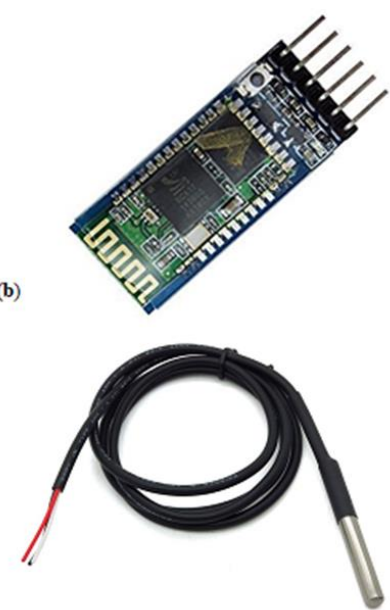

(d)

Figure 2. Main units of the sensors circuit: (a) Arduino UNO, (b) Bluetooth HC-05, (c) pH sensor, (d) Temperature sensor

\subsubsection{Arduino UNO Unit}

The Arduino UNO in Figure 2(a) is the microcontroller unit in the sensors circuit, which reads the data from the sensors and sends on the results. The Arduino UNO is one microcontroller from a family of ATmega328 microcontrollers that has 6 PWM pins, 8 Analog I/O pins, 22 digital input/output pins, and a 16 $\mathrm{MHz}$ clock speed. Table 2 shows the Arduino unit main properties. Figure 3 shows the main open access programing window that is used to program the Arduino microcontrollers.

Table 2. The main properties of Arduino UNO [16]

\begin{tabular}{cc}
\hline Microcontroller & ATmega328 \\
\hline Input Voltage & $7-12 \mathrm{~V}$ \\
Operating Voltage & $5 \mathrm{~V}$ \\
No. of Digital I/O Pins & 14 \\
No. PWM output Pins & 6 \\
No. of Analogue Input Pins & 6 \\
DC Current per I/O Pin & $50 \mathrm{~mA}$ \\
Flash Memory & $32 \mathrm{~KB}$ \\
SRAM and EEPROM & $2 \mathrm{~KB}$ and $1 \mathrm{~KB}$ \\
\hline
\end{tabular}

\subsubsection{The Bluetooth Unit}

The Bluetooth HC-5 unit in Figure 2(b) is used to create a wireless communication between the system application device and the sensors circuit. The PCB antenna of this Bluetooth is on board, and the main properties of the Bluetooth HC-5 board is shown in Table 3.

Table 3. The Bluetooth HC-5 Properties [20]

\begin{tabular}{cc}
\hline Input Voltage & $3.3 \mathrm{~V}$ \\
\hline Communication Distance & Up to 10 metres \\
Baud Rate & (9600 Default), 19200,38400, 57600, \\
Data & $115200,230400,460800$ \\
Stop bit: 1 & 1Byte \\
Parity & I Bit \\
\hline
\end{tabular}




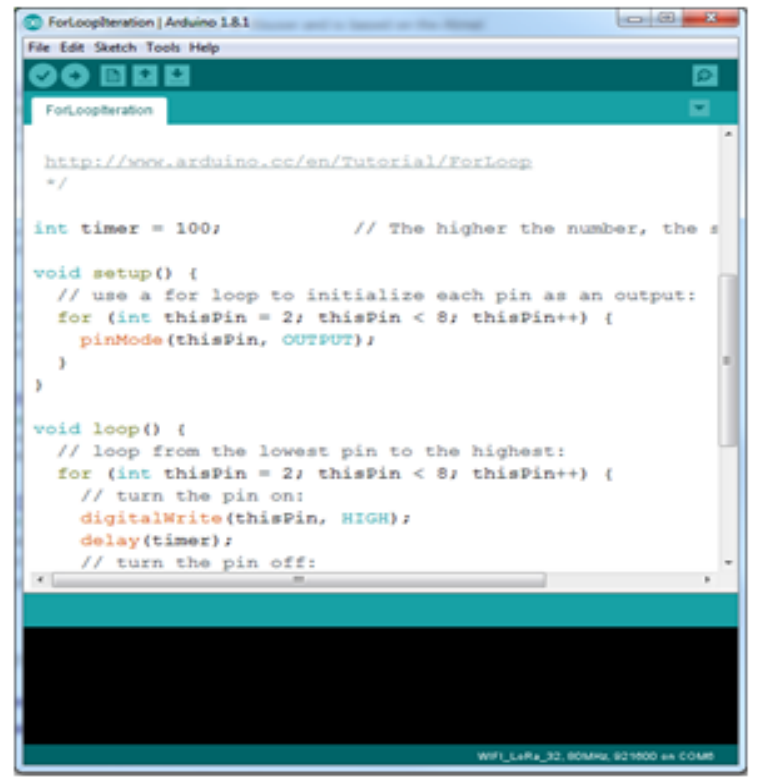

Figure 3. Arduino platform widow

\subsection{3. pH Sensor Unit}

The $\mathrm{pH}$ sensor, or $\mathrm{pH}$ meter, in Figure 2(c) is an instrument used to measure the acidity or alkalinity of the fish farm's water. $\mathrm{pH}$ is the unit of measurement that describes acidity or alkalinity. Figure 4 shows that the measuring scale of $\mathrm{pH}$ ranges from $(0-14)$. The $\mathrm{pH}$ value is The value of $\mathrm{pH}$ can be defined as the hydrogen ion $(\mathrm{H}+)$ ratio to the hydroxyl ion $(\mathrm{OH}-)$ ratio in case of $\mathrm{H}+$ is more than $\mathrm{OH}-$, then the $\mathrm{pH}$ measurement less than 7, and that means it is an acidic material, but If $\mathrm{H}+$ less than $\mathrm{OH}_{-}$, the $\mathrm{pH}$ measurement is more than 7, and the material is alkaline, but if $\mathrm{H}+$ is equal to $\mathrm{OH}-$, the $\mathrm{pH}$ measurement is equal to 7 , and the material is neutral.

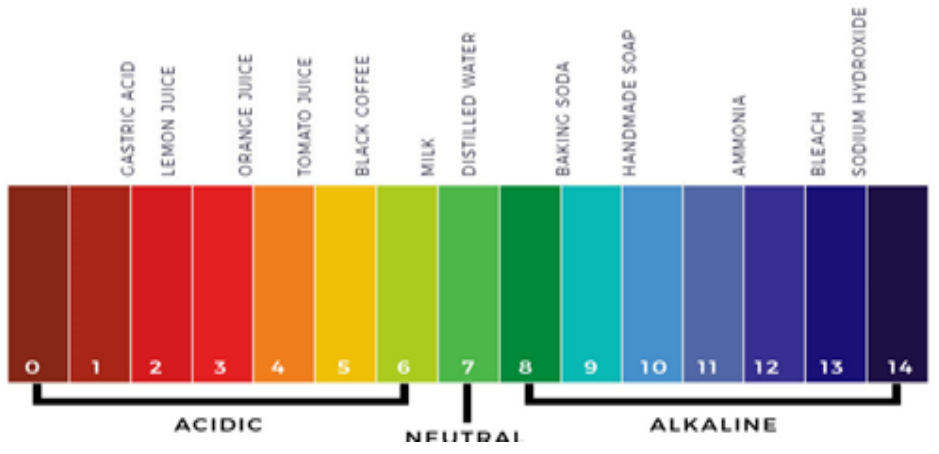

Figure 4. Measure scale of the $\mathrm{pH}$ sensor [23]

\subsubsection{Temperature Sensor Unit}

The DS18B20 in Figure 2(d) is a waterproof one-wire temperature sensor. Its main properties are that it can communicate using a one-wire method to measure a wide ranging temperatures, between $-55^{\circ} \mathrm{C}$ to $+125^{\circ} \mathrm{C}$, with accuracy $\pm 5^{\circ} \mathrm{C}$. The output resolution is 9 - 12 bit, and the conversion time is $750 \mathrm{~ms}$ at $12 \mathrm{bit}$.

\subsection{Monitoring (Smartphone Application)}

The monitoring application of SMWQ software was designed by 'MIT App Inventor 2' to be installed onto an Android instrument, such as a smartphone or tablet. The 'MIT App Inventor 2' is a new opensource blocks platform-based environment application allowed by Google. This platform is used to create Android smartphone applications. Figure 5 shows the 'MIT App Inventor 2' platform, and the main window presents the test, label, and image etc. 


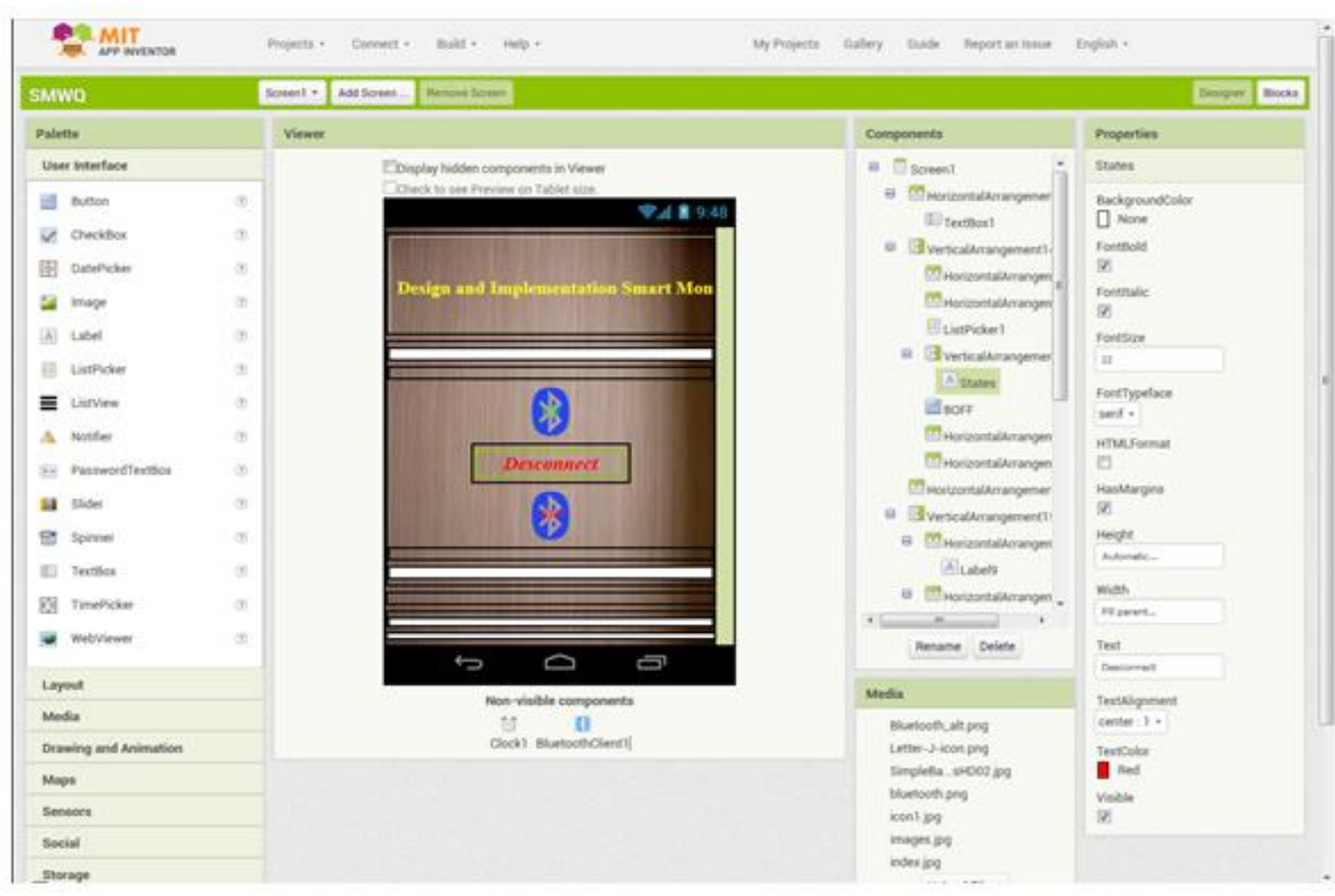

Figure 5. The 'MIT APP Inventor 2' Main screen [23]

\section{EXPERIMENTAL RESULTS}

Figure 6 shows The Final system of the SMWQ. This system is consist of five components connected together, which are: (1) Arduino UNO, (2) HC-5 Bluetooth, (3) pH sensors, (4) Temperature sensor and (5) 16*2 LCD. The SMWQ system has been tested in the laboratory by checking the sensor values ( $\mathrm{pH}$ and temperature), presenting the results on the LCD screen, and then sending them to the smartphone application. The monitoring data was acquired by the smartphone application from a distance of up to 10 metres using HC-5 Bluetooth.

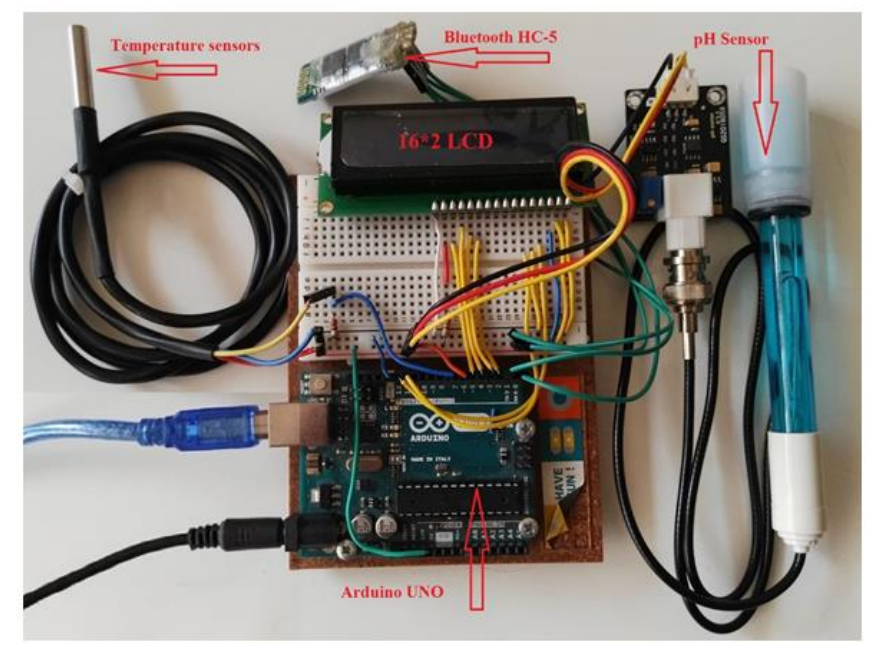

Figure 6. Final headwear design of the SMWQ system

The flowchart of the Arduino UNO process is presented in Figure 7(a). This flowchart shows how the microcontroller measures the $\mathrm{pH}$ and the temperature from the sensors, presents the results on LCD, and then sends by Bluetooth the same results to the end user. The flowchart of the Android application in 
Figure 7(b) shows how the SMWQ application receives the measuring data from the sensor circuit, and presents it on the smartphone instrument.

Figure 8 presents the user interface windows of the SMWQ application. The main interface window of the SMWQ application has two buttons: one for the Bluetooth to connect and disconnect to the sensors circuit, and one to present the $\mathrm{pH}$ and temperature values. Figure 8(a) presents the Bluetooth window, which is used to connect the SMWQ application to the measuring circuit. Figure 8(b) presents the window of the SMWQ application before connecting to Bluetooth and receiving data ( $\mathrm{pH}$ and temperature values) from the sensors circuit, and Figure 8(b) presents the window with output results, after the application has been connected to the sensors circuit.
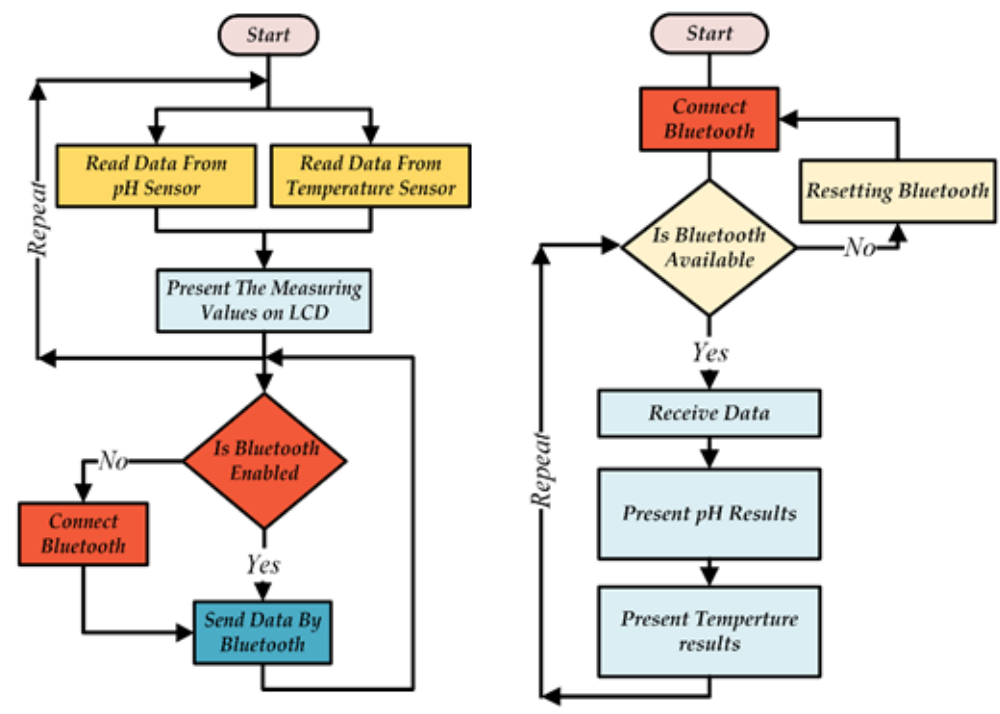

Figure 7. Flowchart of the SMWQ system: (a) Sensors circuit, (b) Smartphone application flowchart
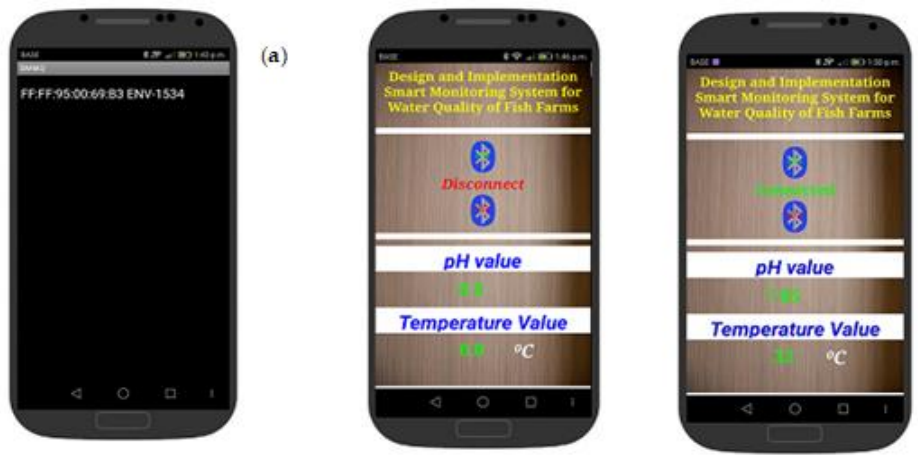

(b)

Figure 8. Windows of the SMWQ application: (a) Bluetooth connection window, (b) Main SMWQ application window before Bluetooth is connected, (c) Main SMWQ application window with results

\section{CONCLUSIONS AND FUTURE WORKS}

In this paper, a low-cost system of a low-cost has been designed to monitor the behaviour of the fish farm's water ( $\mathrm{pH}$ and temperature). We designed and implemented the full smart monitoring system (receiver and transmitter). The prototype transmitter circuit was designed for measuring the $\mathrm{pH}$ and the temperature for the water of fish farm's, and the Arduino Uno was used as a microcontroller reading sensors data then send the results to the receiver by Bluetooth. Bluetooth enables wireless communication between the receiver and transmitter. The receiver part is a new smartphone application, designed by using the 'MIT App Inventor 2', which can be installed onto any Android smartphone. It receives the data of the $\mathrm{pH}$ and 
temperature of the fish farm's water, which is presented on the application. The 'MIT App Inventor 2' is a google software (opensource) that allows you to easily build Android applications. The full system has been tested successfully in a laboratory. Future work should be to change the wireless system from Bluetooth to the Internet of Things (IOT), because IOT technology is the future of communication for smart systems.

\section{REFERENCES}

[1] J. K. Abed, "Smart Monitoring System of DC to DC Converter for Photovoltaic Application," International Journal of Power Electronics and Drive System (IJPEDS), vol. 9, no. 2, pp. 722-729, 2018.

[2] Mnati, MJ, Hasan,A, Bozalakov,DV, Bossche,AV. Smart monitoring and controlling of three phase photovoltaic inverter system using lora technology. 6th Eur. Conf. Ren. Energy Sys. 25-27 June 2018, Istanbul, Turkey

[3] A. Jamaluddin, A. N. A, A. Jumari, and A. Purwanto, "A Monitoring System of Battery LiFePO 4 for Assessment Stand-Alone Street Light Photovoltaic System Based on LabVIEW Interface for Arduino," International Journal of Power Electronics and Drive System (IJPEDS), vol. 8, no. 2, pp. 926-934, 2017.

[4] T. S. Gunawan, I. Rahmithul, H. Yaldi, M. Kartiwi, and N. Ismail, "Prototype Design of Smart Home System using Internet of Things," Indonesian Journal of Electrical Engineering and Computer Science, vol. 7, no. 1, pp. 107-115, 2017.

[5] S. Ghazali, R. Putra, and H. Putra, "Online monitoring of grid connected residential photovoltaic system using zigbee and web server," Indonesian Journal of Electrical Engineering and Computer Science, vol. 7, no. 3, pp. 668675, 2017.

[6] M. J. Mnati, A. Van den Bossche, and R. Chisab, "A Smart Voltage and Current Monitoring System for Three Phase Inverters Using an Android Smartphone Application," Sensors, vol. 17, no. 4, p. 872, 2017.

[7] M. J. Mnati, R. F. Chisab, and A. V. D. Bossche, "A smart distance power electronic measurement using smartphone applications," in 2017 19th European Conference on Power Electronics and Applications, EPE 2017 ECCE Europe, 2017, vol. 2017-Janua, pp. 1-11.

[8] Xingqiao Liu and Liqiang Cheng, “Wireless sensor network based on ZigBee in aquaculture, " Advances in Electronic Commerce, Web Application and Communication, Vol. 148, pp. 553-558, 2012.

[9] Ma Daokun, Ding Qisheng, Li Daoliang, Zhao Linlin, “ Wireless Sensor Network for Continuous Monitoring Water Quality in Aquaculture Farm, "Sensor Letters, Volume 8, Number 1, pp. 109-113(5), 2010.

[10] Qi Lin, Zhang Jian, Mark Xu, Fu Zetian, Chen Wei, Zhang Xiaoshuan, “ Developing WSN-based traceability system for recirculation aquaculture“, Mathematical and Computer Modelling, (53), 2162-2172, 2011.

[11] Mingfei Zhang, Daoliang Li, Lianzhi Wang, Daokun Ma, Qisheng Ding, “ Design and Development of Water Quality Monitoring System Based on Wireless Sensor Network in Aquaculture“, IFIP Advances in Information and Communication Technology, Volume 347, pp 629-641, 2011.

[12] Haifeng W., Binglian W., Xianglong K., Qiang G. , “ Agricultural environment measure system based on Zigbee Network and Algae Cell Sensors“, In: Control Conference, 27, Kunming. Proceedings. pp 209 - 213, 2008.

[13] Soledad Escolar Díaz, Jesús Carretero Pérez, Alejandro Calderón Mateos, Maria-Cristina Marinescu, Borja Bergua Guerra, " A novel methodology for the monitoring of the agricultural production process based on wireless sensor networks", Computers and Electronics in Agriculture, Volume 76, Issue 2, Pages 252-265, 2011.

[14] S. Vyas, "Access Control Application using Android Smartphone Arduino and Bluetooth," vol. 142, no. 9, pp. 16$20,2016$.

[15] Hasan, Ihsan Jabbar, Ghani, Mohd Ruddin Ab, Gan, Chin Kim, “Optimum Substation Placement and Feeder Routing Using GA-MST," Applied Mechanics and Materials; Zurich Vol. 785, (Aug 2015): 9-13. DOI:10.4028/www.scientific.net/AMM.785.9

[16] Available online: https://www.arduino.cc.

[17] T. Du, H. Geng, Y. Sun, H. Lin, H. Lv, and L. Yu, "Design and implement of a low cost control system of active magnetic bearings using LabVIEW Interface for Arduino,” 2017 IEEE Int. Conf. Mechatronics Autom., pp. 1833$1837,2017$.

[18] T. Kaur, J. Gambhir, and S. Kumar, "Arduino Based Solar Powered Battery Charging System For Rural SHS," 2016.

[19] Available online: https://www.dfrobot.com/wiki/index.php/PH_meter(SKU:_SEN0161).

[20] Available online: https://create.arduino.cc/projecthub/TheGadgetBoy/ds18b20-digital-temperature-sensor-andarduino-9cc806 .

[21] R. Perkins, "HC Serial Bluetooth Products User Instructional Manual," California, USA, p. 20, 2012.

[22] Available online: http://appinventor.mit.edu/explore/index-2.html.

[23] Available online: http://bindrdn.waterefficiency.co/ph-test-chart/ . 